Discussion Paper No. 13-045

\title{
Multinationals' Profit Response to Tax Differentials: Effect Size and Shifting Channels
}

Jost H. Heckemeyer and Michael Overesch

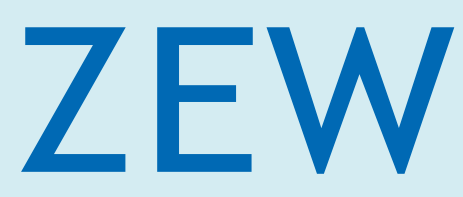

Zentrum für Europäische Wirtschaftsforschung $\mathrm{GmbH}$ Centre for European Economic Research 
Discussion Paper No. 13-045

\title{
Multinationals' Profit Response to Tax Differentials: Effect Size and Shifting Channels
}

\author{
Jost H. Heckemeyer and Michael Overesch
}

Download this ZEW Discussion Paper from our ftp server:

http://ftp.zew.de/pub/zew-docs/dp/dp13045.pdf

Die Discussion Papers dienen einer möglichst schnellen Verbreitung von neueren Forschungsarbeiten des ZEW. Die Beiträge liegen in alleiniger Verantwortung der Autoren und stellen nicht notwendigerweise die Meinung des ZEW dar.

Discussion Papers are intended to make results of ZEW research promptly available to other economists in order to encourage discussion and suggestions for revisions. The authors are solely responsible for the contents which do not necessarily represent the opinion of the ZEW. 


\section{Non-technical summary}

The public debate on tax base erosion by multinational enterprises (MNEs) has been stirred up by strikingly low effective tax rates (ETRs) of some very prominent US-American information technology companies. Going beyond such anecdotal insights, numerous empirical studies provide general evidence for profit shifting by confirming a negative correlation between reported parent or subsidiary profits and local tax levels. Given the current state of research, the existence of profit-shifting behavior is largely unquestioned. Nevertheless, there is much lower a consensus about the scale of the profit-shifting activity and its responsiveness to the crosscountry tax differential allowing for tax arbitrage.

The objective of this paper is to add to the current state of research and debate in two ways. First, we provide a consensus estimate of the size of the tax-rate elasticity of reported parent or subsidiary profits and explain which factors determine the variation in previous empirical findings. Second, we investigate which of the profit-shifting channels generally distinguished, financial structures or transfer pricing, is more important. To this end, we conduct a meta-analysis of the complete literature in both public economics and accounting research that estimates the tax sensitivity of interest.

On the basis of the existing evidence, we predict a tax semi-elasticity of pre-tax profit of about 0.8 , in absolute terms. Hence, reported profits decrease by about $0.8 \%$ if the international tax differential that can be exploited for tax arbitrage increases by 1 percentage point. Moreover, our findings suggest that transfer pricing and licensing, not inter-company debt, is indeed the dominant profit-shifting channel. 


\section{Das Wichtigste in Kürze}

Multinationale Unternehmen können unter Ausnutzung bestehenden Rechts ihre Steuerschuld in bestimmten Regionen beeinflussen und auf diese Weise ihre konzernweite Steuerlast reduzieren. Die öffentliche Debatte um die steuerplanerischen Möglichkeiten multinationaler Konzerne wurde insbesondere am Beispiel einiger bekannter US-Unternehmen aus dem Sektor der Informationstechnologie geführt. Indes liefert die einschlägige wissenschaftliche Literatur Erkenntnisse, die über diese anekdotische Evidenz deutlich hinausgehen.

Angesichts des aktuellen Forschungsstandes ist die Nutzung steuerplanerischer Gestaltungsmöglichkeiten durch multinationale Unternehmen im Grundsatz unbestritten. Weniger Konsens herrscht allerdings hinsichtlich der Frage, in welchem Ausmaß vorhandene Gestaltungsoptionen tatsächlich Anwendung finden und wie gezielt das internationale Steuersatzgefälle so zur Steuerarbitrage genutzt wird.

Ziel dieses Forschungspapiers ist es, den bestehenden Forschungsstand auf zwei Arten zu bereichern. Zum einen wird anhand einer meta-analytischen Auswertung der relevanten Literatur eine Konsensschätzung zum empirischen Zusammenhang zwischen der ausgewiesenen Profitabilität eines Konzernunternehmens und dem anzuwendenden lokalen Steuersatz gefunden werden. Darüber hinaus werden der Literatur Hinweise darauf entnommen werden, welches der möglichen Instrumente der steuerlichen Gestaltung, d.h. steueroptimale Ausrichtung der Finanzierungstruktur oder konzerninterne Transaktionen und Verrechnungspreise, in der Realität bedeutsamer ist.

Im Ergebnis findet sich eine steuerliche Semi-Elastizität des ausgewiesenen Ergebnisses vor Steuern von absolut 0,8. Dies bedeutet, dass das ausgewiesene Ergebnis vor Steuern um ca. 0,8\% sinkt, wenn das für Steuerarbitrage ausnutzbare Steuersatzgefälle um 1 Prozentpunkt zunimmt. Als wesentlicher Treiber der Reaktion erscheint weniger die steueroptimale Finanzierung grenzüberschreitender Investitionen als vielmehr die steueroptimale Strukturierung von Transaktionen im Unternehmen, z.B. in Form grenzüberschreitender Lizensierungsvereinbarungen zwischen Konzerneinheiten. 


\title{
Multinationals' Profit Response to Tax Differentials: Effect Size and Shifting Channels *
}

\author{
Jost H. Heckemeyer ${ }^{a}$ and Michael Overesch ${ }^{b}$
}

July 2013

\begin{abstract}
This paper provides a quantitative review of the empirical literature on profit-shifting behavior of multinational firms. We synthesize the evidence from 25 studies and find a substantial response of profit measures to international tax rate differentials. Accounting for misspecification biases by means of meta-regressions, we predict a tax semi-elasticity of subsidiary pre-tax profits of about 0.8 . Moreover, we disentangle the tax response by means of financial planning from the transfer pricing and licensing channel. Our results suggest that transfer pricing and licensing are the dominant profit-shifting channel.
\end{abstract}

Keywords: Profit Shifting, Multinational Firm, Corporate Income Tax, Meta-Analysis.

JEL Code: H25, H26, H32

${ }^{\text {a }}$ University of Mannheim, Business School, Schloss, 68131 Mannheim, Germany, heckemeyer@uni-mannheim.de.

${ }^{\mathrm{b}}$ University of Cologne, Department of Management and Economics, Albertus Magnus Platz, 50923 Cologne, Germany, overesch@wiso.uni-koeln.de.

* We would like to thank participants of the Congress of the International Institute of Public Finance in Dresden, the European Accounting Association in Paris and the Annual Meeting of the German Association for Business Research in Berlin for valuable comments. 


\section{Introduction}

Recently, the public debate on tax base erosion by multinational enterprises (MNEs) has been stirred up by strikingly low effective tax rates (ETRs) of some very prominent US-American information technology companies. For example, the most valuable US company, Apple Inc., reported a foreign ETR of only 4.7\% for the fiscal year 2011 (Sullivan, 2012). Anecdotal evidence suggests that MNEs such as Apple Inc. or Google Inc. are indeed able to shift taxable profits from high-tax to low-tax jurisdictions. In response to the supposedly widespread use of profitshifting techniques by MNEs around the globe, the OECD (2013), with support from the G20 and individual governments, has taken the initiative and started a major effort to restrain what they call base erosion and profit shifting (BEPS). Moreover, in many countries unilateral proposals are being discussed to limit cross-border income shifting such as, for example, the US president's framework for business tax reform (2012).

Going beyond anecdotal insights, numerous empirical studies provide general evidence for profit shifting by confirming a negative correlation between reported parent or subsidiary profits and local tax levels. Given the current state of research, the existence of profit-shifting behavior is largely unquestioned. Nevertheless, there is much lower a consensus about the scale of the profit-shifting activity and its responsiveness to the cross-country tax differential allowing for tax arbitrage. Accordingly, the OECD report on BEPS concludes that "with the data currently available, it is difficult to reach solid conclusions about how much BEPS actually occurs" (OECD 2013, p.15).

The objective of this paper is to add to the current state of research and debate in two ways. First, we provide a consensus estimate of the size of the tax-rate elasticity of reported parent or subsidiary profits and explain which factors determine the variation in previous empirical find- 
ings. Second, we investigate which of the profit-shifting channels generally distinguished, financial structures or transfer pricing, is more important.

To this end, we conduct a meta-analysis of the complete literature in both public economics and accounting research that estimates the tax sensitivity of interest. Using meta-regression analysis, we can generalize the empirical findings and, in addition, investigate which factors systematically drive their variation. By doing so, we also condense the broad evidence from studies using US data combined with studies using data on MNEs from all over the world.

The meta-database we build contains 238 primary estimates sampled from 25 empirical studies identified by means of article search engines. All studies included in the meta-analysis regress some measure of reported multinational parent or subsidiary profits on the tax incentive to shift profits abroad. The results from our meta-regressions show that the omission of the tax influence on the scale of real economic activity leads to considerable bias with significantly overstated tax effects on profit shifting. Moreover, estimates of the tax response of reported parent or subsidiary profit are affected by using subsidiary-level data, a careful modeling of the worldwide tax incentive of the multinational firm and the inclusion of industry-fixed effects. On the basis of the existing evidence and accounting for all misspecification biases, we predict a tax semi-elasticity of pre-tax profit of about 0.8 , in absolute terms. Hence, reported profits decrease by about $0.8 \%$ if the international tax differential that can be exploited for tax arbitrage increases by 1 percentage point.

While empirical evidence for profit shifting is generally significant and clear, there is still little knowledge about the relative importance of the channels employed to shift profits from high to low-tax jurisdictions. Two routes are generally distinguished. First, MNEs choose tax-efficient financial structures. Second, MNEs can use non-financial techniques like transfer pricing and 
licensing. While only a few studies have attempted to figure out the relative importance of the two channels, their results are even contradictory. Grubert (2003) argues that the shifting volume of US firms can be almost equally attributed to financial structures and non-financial shifting techniques. On the contrary, Dharmapala and Riedel (2012) state that according to their empirical approach profit-shifting effects should be mainly attributed to the strategic use of debt.

Our meta-analysis can provide additional insights in the relevance of shifting channels that are hidden behind the voluminous evidence already at hand. Pointing to the synthesized evidence, we infer the dimensions of the shifting channels which are implicit in the prior findings. We disentangle the tax response by means of financial planning from the transfer pricing and licensing channel. More specifically, we systematically compare the tax sensitivity of pre-tax profits, capturing shifting activity via both routes, with the tax sensitivity of earnings before interest and taxes (EBIT) which are only affected by non-financial shifting mechanisms. Our stylized calculations suggest that transfer pricing and licensing, not inter-company debt, is indeed the dominant profit-shifting channel.

Potential uses for our results are manifold. First, the effect size derived from a meta-regression can be interpreted as a sort of consensus estimate (Florax et al., 2002) which combines all available information on the empirical relationship at stake, conditional on state-of-the-art study design. Such a consensus can improve the calibration of policy models because it reflects the complete knowledge contained in the abundant empirical literature. Policy analyses based on metaregression results avoid the highly selective and arbitrary use of model parameters, considered as a traditional weakness of many empirical models (Steiner, 2008). Second, identification of the most important shifting channels is helpful because tax rules asymmetrically affect shifting tech- 
niques. Moreover, the design and effectiveness of anti-avoidance rules depends highly on the shifting channel at which it is targeted.

Last but not least, the meta-regression analysis can guide future empirical research. It uncovers potential sources of bias by showing which study characteristics determine the empirical results. Future improvements in estimation techniques could also be evaluated against the benchmark provided by the meta-regression results.

The remainder of the paper is organized as follows. In Section 2, a description of the metaregression investigation approach and our database is provided. Thereafter, in Section 3 the metavariables are described. The results of the meta-regressions are presented in Section 4. In Section 5 we use the results from the meta-regression to discuss the economic significance of the different shifting channels. Finally, Section 6 concludes.

\section{Methodology and Data}

\subsection{The Meta-Regression Approach}

Econometric analyses in empirical economics differ in terms of sample characteristics and estimation methodology. In contrast to randomized trials, reported estimates thus vary beyond pure sampling error. Meta-regression analysis is a statistical approach to generalize the central tendency of a strand of literature and to explain the heterogeneity in empirical findings (Smith and Glass, 1977; Stanley, 2001; Disdier and Head, 2008). It has been increasingly employed in diverse fields of economics. In international taxation, De Mooij and Ederveen (2003) provide a meta-regression analysis on the tax elasticity of FDI. Moreover, Feld, Heckemeyer and Overesch (2013) use meta-analysis to explain the variety of reported marginal tax effects on capital struc- 
tures. Very recently, Adam, Kammas and Lagou (2013) presented a meta-study on the effect of globalization on capital taxation. ${ }^{1}$

For any meta-regression to be meaningful, it must combine estimates that are actually comparable. Certainly, studies investigating profit-shifting activities of multinational firms look at rather diverse empirical relationships. For obvious reasons, the tax effect on transfer pricing cannot be compared to the one on the debt-to-asset ratio or on reported profits. As a consequence, we limit the focus of this meta-analysis to those studies that are interested in the tax sensitivity of some measure of profitability. This strand of literature is often referred to as providing indirect evidence of profit-shifting activity. Overall, we include 25 studies in our meta-sample, out of a universe of more than 50 studies which, directly or indirectly, deal with profit shifting.

To guarantee that all tax effects included in this quantitative survey are measured on the same scale, we consistently refer to the tax semi-elasticity of profits. The semi-elasticity indicates the percentage change of reported profit in response to a one percentage point change in the tax incentive to shift profits abroad. The tax incentive to shift profits is equal to the exploitable international tax rate differential:

$$
\text { semi-elasticity }=\frac{\% \text { change in reported profits }}{\text { change in the tax differential }}
$$

The meta-regression we estimate takes the linear form depicted in equation (2), where $y$ corresponds to the vector of tax semi-elasticities drawn from primary analyses and $\boldsymbol{X}$ is a matrix of predominantly dummy variables that reflect various study or model characteristics.

$$
y=X \beta+\varepsilon
$$

\footnotetext{
${ }^{1}$ Other recent applications are found, for example, in the field of international economics by Havranek and Irsova (2011) or Disdier and Head (2008), in labor economics by Card et al. (2010), and in health economics by Doucouliagos et al. (2012).
} 
The coefficient for each dummy variable gives the estimated impact on the conditional mean of reported tax effects if the study design features the respective characteristic.

The error term $\boldsymbol{\varepsilon}$ of the meta-regression equation (2) is clearly heteroskedastic because the precision of primary effect estimates $\operatorname{Var}(\mathbf{y} \mid \mathbf{X})$ varies with the attributes of primary studies coded in $\boldsymbol{X}$. As a consequence, ordinary least squares estimation of (2) could be extremely inefficient (Greene, 2003: 226). To cope with this issue, we will use weighted least squares (WLS) to estimate equation (2), which is the standard procedure employed to obtain efficient meta-regression estimates (Stanley, 2008). By weighing each primary estimate with its inverse standard error, reliable estimates of the semi-elasticity are given a larger weight in the meta-regression estimation than those which are imprecisely estimated.

\subsection{The Tax Effects Data Set}

Many studies in the surveyed strand of research use a log-level specification which implies, conveniently, that they immediately report point estimates of the semi-elasticity in (1). We briefly explain the basic rationale for the common specification along the lines of Huizinga and Laeven $(2008){ }^{2}$ First, acknowledge that reported subsidiary pre-tax profits in country $i$, denoted $P_{i}^{r}$, are equal to the sum of unobserved true pre-tax profits $P_{i}$ and those profits shifted into or out of country $i$, denoted $S_{i}{ }^{3}$ The scale of profit shifting depends on the international tax differential between country $i$ and other subsidiary locations $j \neq i, \Delta \tau_{i, j}$, and the semi-elasticity $\gamma$.

$$
P_{i}^{r}=P_{i}+\underbrace{P_{i} \gamma \Delta \tau_{i, j}}_{=S_{i}}=P_{i}\left(1+\gamma \Delta \tau_{i, j}\right)
$$

Taking logs, this equation (3) is approximated by

\footnotetext{
${ }^{2}$ For a more specific and detailed derivation of the estimation approach, please refer to Huizinga and Laeven (2008).

${ }^{3}$ We omit group, subsidiary, and time indices.
} 


$$
\ln P_{i}^{r}=\ln P_{i}+\gamma \Delta \tau_{i, j}
$$

Now assume a Cobb-Douglas production function with output given by $Q_{i}=c A_{i}^{\mu} L_{i}^{\alpha} K_{i}^{\omega} e^{v_{i}}$ with $A_{i}$ as a productivity parameter, $K_{i}$ as capital and $L_{i}$ as labour input; $\mu, \alpha$, and $\omega$ are output elasticities, $c$ is a scale parameter, and $v_{i}$ is a random term. Unobserved true profits $P_{i}$ are equal to the production output $Q_{i}$ minus the wage bill. Substituting for $\ln P_{i}$ into equation (4), the most common estimation equation in the literature is obtained:

$$
\ln P_{i}^{r}=\beta_{1}+\beta_{2} \ln A_{i}+\beta_{3} \ln L_{i}+\beta_{4} \ln K_{i}+\gamma \Delta \tau_{i, j}+v_{i}
$$

Considering the empirical literature to be evaluated, we collect the point estimates for the tax effect, $\gamma$.

All relevant studies were identified by comprehensively searching the EconLit database. More specifically, we searched the database for the central keywords "Income Shifting", "Profit Shifting" and "Tax". Furthermore, we conducted additional internet searches and scanned relevant journals as well as working paper series. ${ }^{4}$ Our last update of the database took place in April 2013. In total, we found more than 50 studies to match our search criteria. However, we include only those studies that employ a profit measure as their dependent variable. That means, all studies estimating tax effects on price data, intercompany sales or debt-to-asset ratios are excluded from our meta-analysis. Moreover, we can only consider studies that directly provide tax semielasticities or allow for the transformation of reported effects at sample means. If the required

\footnotetext{
${ }^{4}$ We particularly searched through the Journal of Public Economics, American Economic Journal: Economic Policy, Journal of International Economics, National Tax Journal, International Tax and Public Finance, Accounting Review, Journal of Accounting Research, Journal of Accounting and Economics, Contemporary Accounting Research, European Accounting Review, and the SSRN working paper database.
} 
information to construct semi-elasticities is not available, we have to exclude the study from our meta-analysis. ${ }^{5}$

Table 1: Descriptive Statistics

\begin{tabular}{|c|c|c|c|c|c|c|c|}
\hline & \multirow{2}{*}{$\begin{array}{l}\text { No. of } \\
\text { studies }\end{array}$} & \multirow{2}{*}{$\begin{array}{l}\text { No. of } \\
\text { Effects }\end{array}$} & \multicolumn{5}{|c|}{ Tax Semi-Elasticities } \\
\hline & & & Mean & Median & Min & Max & Std. \\
\hline After-financing profit & 22 & 161 & 1.78 & 0.97 & -1.33 & 24.30 & 2.54 \\
\hline EBIT & 6 & 77 & 1.07 & 1.01 & -5.91 & 4.87 & 1.22 \\
\hline Full Sample & 25 & 238 & 1.55 & 0.99 & -5.91 & 24.30 & 2.23 \\
\hline
\end{tabular}

The full sample includes all tax semi-elasticities of both profit and EBIT of multinational subsidiaries.

In total, we extract 238 observations out of 25 studies, with each observation representing one estimate of the tax semi-elasticity of either reported profit or earnings before interest and taxes (EBIT). ${ }^{6}$ Table 1 provides some descriptive statistics. Detailed statistics for every primary study can be found in Table 4 in the Appendix. Please note that, for convenience of presentation, we pre-multiply semi-elasticities reported in the literature by (-1) before entering them into our metadataset and doing the meta-regression analysis.

The distinction between total profits and EBIT is a nice feature of the literature. While the former group of estimations analyzes the total tax response of profit including all possible shifting channels, the latter clearly excludes the tax effect originating from inter-company financing. We can make use of this difference to figure out whether inter-company financing or, instead, transfer pricing is the most important shifting channel.

\footnotetext{
${ }^{5}$ Excluded studies are, for example, Grubert and Mutti (1991), Jacob (1996), Grubert (1998), Bartelsman and Beetsma (2003), and Clausing (2003).

6 Following a standard convention in the meta-analysis literature (e.g. Disdier and Head, 2008; Havranek and Irsova, 2011; Feld et al., 2013), we try to sample all tax effect estimates reported in these studies. ${ }^{6}$ Discarding information would be inefficient. In particular, selecting one single estimate from each study would require predefined and objective sampling rules, which can hardly be justified. Moreover, the additional heterogeneity obtained from considering all robustness checks reported in a study is welcome in statistical meta-analyses.
} 
The early empirical literature included in the meta-sample dates back to the 1990s. Grubert and Mutti (1991) and Hines and Rice (1994) use aggregate Bureau of Economic Analysis (BEA) data of US corporations' foreign subsidiaries. In addition to profit, Hines and Rice (1994) also employ EBIT as a dependent variable. Numerous studies follow up. Recent contributions based on BEA data include Clausing (2009) and Blouin et al. (2012). Contrary to these studies, Mills and Newberry (2004) examine whether the tax incentives of non-US multinationals influence their U.S. subsidiary tax reporting. More recently, improved availability of firm-level data has led to an increasing number of studies dealing with income shifting also in a non-US context. Huizinga and Laeven (2008) as well as Dharmapala and Riedel (2012), for example, use European data from the Amadeus database. Moreover, Weichenrieder (2009) exploits data on German inbound and outbound FDI.

After all, as shown in Table 1, most empirical contributions to the profit-shifting literature refer to profit net of interest. These 22 studies contribute 161 semi-elasticities to the meta-sample. The mean semi-elasticity in this class of literature is 1.78 , with a median effect size of 0.97 . The maximum value of 24.3 is reported by Hines and Rice (1994) and the smallest responsiveness is found in Schwarz (2009). Six of the 25 studies with a total of 77 estimates focus on the tax sensitivity of EBIT and thus analyze income shifting via related-party transactions. The mean semielasticity reported in these studies amounts to 1.07 , with a median value of 1.01 . Extreme values are -5.91 and 4.87, respectively reported by Hines and Rice (1994) and Maffini and Mokkas (2011). Note that the standard deviation of the 238 estimates collected from the literature is larger than 2. Given the sample mean of 1.55, the coefficient of variation (standard deviation/mean) exceeds the value one. Table 4 in the Appendix, showing descriptive statistics separately for every primary study, corroborates the finding of considerable heterogeneity in reported tax semi- 
elasticities, not only between but also within studies. In the following, we will attempt to systematically explain this variation in the empirical literature.

\section{Why Identified Tax Effects Might Vary}

We expect the following study attributes to drive the identified tax effect on profit measures, beyond mere sampling error: the scope of the profit-shifting channels considered by the primary regressions, control for the economic activity of subsidiaries, the employed proxy for the tax incentive, the econometric specification used in the analysis, and structural heterogeneity of the firm data used by primary studies.

\subsection{Scope of Profit-Shifting Analyzed}

Regarding the categories of dependent variables employed in the literature, we distinguish between pre-tax profit and EBIT. The tax effect on EBIT does only reflect part of the tax response of profit. While the pre-tax profit of a subsidiary is influenced by all types of profit shifting, we know that EBIT is clearly independent of financial structures. Interest income and interest paid from both internal as well as external debt is not reflected in the EBIT measure. Consequently, significant tax effects of EBIT found in primary studies can be related to non-financial shifting techniques like transfer pricing and royalty payments. Consequently, we expect a significantly smaller tax effect on EBIT than on profits. Therefore, we consider a dummy variable After Financing Profitability which marks primary tax effects on pre-tax profit.

Some studies explicitly consider a proxy for debt financing as a shifting channel and control for the subsidiary's debt share. Then, the tax effect on profit measures is expected to be downward biased because the debt share is also positively correlated with the tax incentive to shift 
profits. Therefore, we consider an additional dummy variable Control for Debt Share which is one if the primary specification takes into account the debt share as a control and zero otherwise.

\subsection{Dependent Variable Characteristics}

Regarding the categories of dependent variables employed in the literature, we distinguish between profit measured before and after taxes. While any correlation between pre-tax profitability and the tax rate can be attributed to behavioral responses to taxes, after-tax profit measures are also directly affected by the taxes paid. Therefore, we expect a more pronounced tax response if the dependent variable is measured after taxes compared to pre-tax measures. Consequently, we consider a meta-variable Profits Before Taxes which is one if the dependent variable in primary studies refers to a profit measure before taxes and zero otherwise.

\subsection{Proxy for the Tax Incentive}

Tax rate differentials within the MNE create the incentive to shift reported profits. The measurement of the tax incentives, however, is a non-trivial task. MNEs usually have several subsidiaries, and shifting is not restricted to a certain affiliate. In fact, the number of potentially relevant tax differentials increases with each additional affiliate. Moreover, some tax rate differentials do not contribute much to the shifting incentive because only a small number of bilateral transactions that can be effectively mispriced for profit-shifting purposes take place. Therefore, some studies use a simple heuristic and rely on host country tax rates only. This approach is simplifying and should be associated with some omitted variable bias. To maximize the potential for tax arbitrage and profit shifting, one expects, for example, parent firms in high-tax countries to have subsidiaries in low-tax countries, and vice versa. To the extent that this is the case, the mere consideration of the host country tax rate would yield estimates for the tax coefficient that are biased 
toward larger effect sizes (Huizinga and Laeven, 2008). For this reason, some studies attempt to approximate the worldwide tax incentive for the MNE and apply more refined measures of the tax rate differential. A number of studies refer to the bilateral tax rate differential between the home country of the parent and the host country. Other studies however consider a weighted average tax rate differential for the MNE (Collins et al., 1998; Mills and Newberry, 2004; Huizinga and Laeven, 2008; Grubert, 2012). In our meta-regressions we consider a binary variable Worldwide Tax Incentive Considered to distinguish primary studies that approximates the worldwide tax incentive of the MNE by some form of tax rate differential from studies referring to the host country tax rate only.

The tax incentive of profit shifting is, in principle, driven by tax savings associated with one additional dollar of shifted income. Apart from differences in tax legislations, firm-specific characteristics also affect the marginal tax savings. In particular, the existence of losses can change the profit-shifting incentive. If a subsidiary suffers from losses, an additional profit is effectively not taxed, although the statutory tax rate or taxes reported in previous financial accounts may be high nonetheless. Including loss-making subsidiaries in an empirical analysis of profit shifting can therefore be associated with an additional measurement error of the tax incentive. We add a dummy variable Loss Making Firms Excluded to our meta-regressions to capture the potential improvement of the measurement precision if subsidiaries suffering losses are excluded from the sample considered by the primary study.

\subsection{Controlling for the Scale of Affiliates' Real Activities}

Low tax levels do not only attract paper profits but also real economic investment in production plants and sales departments. The additional investment should be associated with additional amounts of profits. Consequently, the tax effect on subsidiaries' reported profit might be overes- 
timated if the empirical specification does not adequately control for the scale of their local economic activity (Clausing, 2006).

True pre-tax earnings in the absence of any profit shifting are a function of the MNE's real economic activity. Therefore, several studies control for factors determining the production function. Accordingly, we use a dummy Control for Real Activity which is one if the primary empirical investigation was designed to isolate pure profit-shifting effects from capital location effects induced by international tax differences. Therefore, the dummy takes on the value of one if profit is either scaled by the size of local business activity to give a consistent measure of local profitability as a left-hand side variable, or if the size of local economic activity is controlled for on the right-hand side of the primary estimation equation.

Primary studies consider either assets or payroll as proxies for the scale of affiliate production. In additional regressions we distinguish between control variables and use the two dummies Control for Affiliate Capital and Control for Affiliate Payroll which are one if the primary specification includes some proxy for assets, respectively payroll, of the analyzed subsidiaries.

\subsection{Econometric Specification of Primary Studies}

Profitability varies considerably between firms. However, firms also differ with respect to their tax aggressiveness. Dyreng, Hanlon and Maydew (2010), for example, find that management characteristics determine the tax aggressiveness of firms. Moreover, profit shifting often contradicts the interest of local managers. Local managers might want to avoid the disciplining effects of debt financing or enjoy bonuses tied to their subsidiary's profitability. Therefore, some empirical analyses control for such unobserved subsidiary-specific heterogeneity. On the one hand, it might correct for omitted variable bias. On the other hand, subsidiary fixed effects nest country fixed effect. Then, modeling subsidiary-fixed effects might reduce identified tax effects 
on profitability because much of the cross-sectional tax rate variation is absorbed (Clausing, 2006: 276).

Effective shifting opportunities are determined by the details of the tax code and tax enforcement of both home and host countries. For example, obligations on document transfer prices or thin-capitalization rules affect the opportunity to shift profits away. Interestingly, only Beuselinck, Deloof and Vanstraelen (2009) have included detailed measures of anti-avoidance rules (here: transfer pricing documentation). However, if the anti-avoidance rules do not vary much over time, subsidiary fixed effects can help to control the heterogeneity in profit-shifting opportunities across host countries.

To find out whether the inclusion of subsidiary fixed effects has an impact on the size of the identified semi-elasticities, we define a binary dummy variable Firm Fixed Effects Included which marks estimates resulting from analyses where subsidiary-fixed effects are modeled.

While transfer prices have to conform to the internationally accepted arm's length principle, in the case of firm-specific assets like intellectual property or services, market prices do not exist. Therefore, opportunities to manipulate transfer prices are heavily determined by business strategies and transaction types. Approximation of the heterogeneity in shifting opportunities across firms is a challenging task. Nevertheless, we code the binary dummy variable Industry Fixed Effects Included marking estimates from specifications that control for heterogeneity across business models by including industry fixed effects.

There can also be unobserved time trends affecting the profitability, e.g. business cycle effects, financial crises or changes in the institutional environment. Unmodeled time trends supposedly affect measured tax effects on profitability. We therefore code a binary dummy variable 
Time Fixed Effects Included marking primary estimates free of any potential biases resulting from unmodeled time trends.

\subsection{Data Sample Characteristics}

While most empirical studies consider subsidiary-level data, a few studies employ country level data (for example, Hines and Rice, 1994). Data aggregated at the host-country level also include the external margin of FDI. Then, the well-known negative tax effect on location choices might add to the profit-shifting effect in reported profits. Therefore, we expect significantly higher tax effects if data used in primary studies are aggregated at the host-country level. We consider a variable Micro-Level Data which is one if the primary study employs subsidiary-level data.

The data used in primary empirical studies is disclosed at very different dates. Hines and Rice (1994) estimate tax coefficients based on cross-sectional data for 1982. Huizinga and Laeven (2008) provide evidence based on year 1999 data. Dischinger and Riedel (2011), for example, use panel data for the period from 1995 through 2005 . The intensity of the behavioral response to taxes might vary over time because tax advisors are always searching for new tax planning strategies. Still, it is an empirical question whether the refinement in potential profit shifting strategies is offset by the introduction of specific anti-avoidance rules. We therefore consider in our metaregression a variable Average Sample Year, which is the average disclosure year of the data used in the underlying estimation.

The 25 studies in our meta-sample are based on 6 different databases, which differ in terms of geographical coverage and types of firm represented. Some databases, e.g. data from the Bureau of Economic Analysis (BEA), exclusively cover MNE data from only one home country. Others, e.g. the Amadeus or Orbis databases, cover cross-country firm data. The home country of an MNE might also affect the incentives and opportunities to shift profits across subsidiaries. First, 
the taxation of profits repatriated from foreign subsidiaries influences the profit-shifting incentives. Most countries simply exempt foreign dividends from taxation (exemption system). In this case, an MNE definitely benefits from reductions in foreign tax payments due to profit shifting. By contrast, in some countries, e.g. the US, foreign income is taxed but foreign tax payments can be deducted from domestic tax liabilities (credit system). Then, the gains from profit shifting across foreign affiliates tend to be eliminated upon repatriation of profits.

Some databases only contain information on publicly listed firms; others also include unlisted small and medium-sized firms. Finally, the data coverage varies due to very different reporting obligations and data collection procedures across countries. In order to capture the heterogeneity of data used in primary studies, we will control for database fixed effects in our meta-regressions.

\section{Results of the Meta-Regression}

\subsection{Benchmark Study}

The results of our meta-regression analysis are displayed in Table 2. Following a standard convention in meta-studies (cf. Stanley, 2008), we address the heteroskedasticity in the metaregression error term by WLS techniques. Precisely, the meta-regression observations are weighted with the inverse of their reported standard error before applying standard ordinary least squares (OLS). By giving precise and reliable observations a greater influence, the metaregression estimation becomes much more efficient. All specifications include database fixed effects.

In specification (1) we consider meta-variables regarding the control for the size of affiliate real economic activities and the scope of profit shifting considered in primary studies. Regression (2) also takes into account the approximation of the firm-specific shifting incentive, while regres- 
sion (3) is augmented by data sample characteristics of primary analyses. In Column (4), we consider the meta-variables reflecting the different econometric specification in primary analyses. Finally, in column (5) we distinguish between different controls for the real activity size of multinational affiliates.

The coefficients for each dummy variable reflect the average impact on reported tax semielasticities if the study design deviates from the underlying benchmark in that specific aspect. Significant meta-regression coefficients suggest that econometric specification and control variables included in primary studies indeed affect the tax effects found in the literature. Therefore, for a discussion of the results, it is helpful to begin with the benchmark study, which is implicitly defined by the specification of our meta-regression equation. The benchmark study is a hypothetical primary analysis of the tax effect on subsidiary profit. The explanatory dummy variables included in the meta-regression reflect deviations from this particular benchmark specification. Accordingly, we are able to carefully predict a typical tax semi-elasticity for such a hypothetical benchmark analysis (and any possible enhancements).

The benchmark study lacks all study characteristics denoted in Table 2 that are statistically significant. The benchmark predictions will thus be subject to all identified significant biases. If meta-regression coefficients are instead insignificant, we set corresponding dummy variables at their sample means and thus implicitly refer to the "average study" of the sample. Moreover, predicted marginal tax effects are evaluated at the sample mean of Average Sample Year. Similarly, database dummies are also considered at sample means, independent of significance. We do so in order to predict typical tax effects and generalize empirical findings, rather than referring to specific data. 
Table 2: Meta-Regression of Reported Semi-Elasticities of Profit versus EBIT

\begin{tabular}{|c|c|c|c|c|c|}
\hline & (1) & (2) & (3) & (4) & (5) \\
\hline \multicolumn{6}{|l|}{ Scope of Profit Shifting Analyzed } \\
\hline After-Financing Profitability & $\begin{array}{c}0.293 * * * \\
(0.0982)\end{array}$ & $\begin{array}{c}0.290 * * * \\
(0.104)\end{array}$ & $\begin{array}{l}0.215 * * \\
(0.0858)\end{array}$ & $\begin{array}{c}0.346^{* * *} \\
(0.106)\end{array}$ & $\begin{array}{c}0.344 * * * \\
(0.105)\end{array}$ \\
\hline Control for Debt Share & $\begin{array}{c}-0.391 * * * \\
(0.145)\end{array}$ & $\begin{array}{c}-0.404 * * * \\
(0.151)\end{array}$ & $\begin{array}{c}-0.352 * * \\
(0.140)\end{array}$ & $\begin{array}{c}-0.321 * * \\
(0.137)\end{array}$ & $\begin{array}{c}-0.324 * * \\
(0.140)\end{array}$ \\
\hline \multicolumn{6}{|l|}{ Dependent Variable Characteristics } \\
\hline Profits Before Taxes & $\begin{array}{c}-0.785 * * * \\
(0.196)\end{array}$ & $\begin{array}{c}-0.784 * * * \\
(0.226)\end{array}$ & $\begin{array}{c}-0.854 * * * \\
(0.228)\end{array}$ & $\begin{array}{c}-0.951 * * * \\
(0.217)\end{array}$ & $\begin{array}{c}-0.942 * * * \\
(0.219)\end{array}$ \\
\hline \multicolumn{6}{|l|}{ Control for the Size of Affiliate Activ- } \\
\hline Control for Real Activity & $\begin{array}{c}-0.561 * * * \\
(0.138)\end{array}$ & $\begin{array}{c}-0.557 * * * \\
(0.171)\end{array}$ & $\begin{array}{c}-0.513 * * * \\
(0.176)\end{array}$ & $\begin{array}{c}-0.571 * * * \\
(0.202)\end{array}$ & \\
\hline Control for Affiliate Capital & & & & & $\begin{array}{c}-0.585^{* *} \\
(0.227)\end{array}$ \\
\hline Control for Affiliate Payroll & & & & & $\begin{array}{l}0.0421 \\
(0.186)\end{array}$ \\
\hline \multicolumn{6}{|l|}{ Proxy for the Tax Incentive } \\
\hline Worldwide Tax Incentive Considered & & $\begin{array}{c}-0.107 \\
(0.196)\end{array}$ & $\begin{array}{c}-0.124 \\
(0.190)\end{array}$ & $\begin{array}{c}-0.429 * * \\
(0.205)\end{array}$ & $\begin{array}{c}-0.441 * * \\
(0.212)\end{array}$ \\
\hline Loss-Making Companies Excluded & & $\begin{array}{l}0.0985 \\
(0.129)\end{array}$ & $\begin{array}{c}0.214 \\
(0.131)\end{array}$ & $\begin{array}{c}0.203 \\
(0.141)\end{array}$ & $\begin{array}{c}0.198 \\
(0.140)\end{array}$ \\
\hline \multicolumn{6}{|l|}{ Data Sample Characteristics } \\
\hline Micro-Level Data & & & $\begin{array}{c}-1.901 * * * \\
(0.418)\end{array}$ & $\begin{array}{c}-2.086^{* * *} \\
(0.377)\end{array}$ & $\begin{array}{c}-2.101 * * * \\
(0.368)\end{array}$ \\
\hline Average Sample Year & & & $\begin{array}{r}-0.00945 \\
(0.0137)\end{array}$ & $\begin{array}{c}-0.0344 * * \\
(0.0157)\end{array}$ & $\begin{array}{c}-0.0344 * * \\
(0.0157)\end{array}$ \\
\hline \multicolumn{6}{|l|}{ Econometric Specification of Primary } \\
\hline Firm Fixed Effects Included & & & & $\begin{array}{l}-0.147 \\
(0.138)\end{array}$ & $\begin{array}{l}-0.159 \\
(0.141)\end{array}$ \\
\hline Industry Fixed Effects Included & & & & $\begin{array}{c}0.392 * * * \\
(0.118)\end{array}$ & $\begin{array}{c}0.385 * * * \\
(0.117)\end{array}$ \\
\hline Time Fixed Effects Included & & & & $\begin{array}{c}0.0498 \\
(0.150)\end{array}$ & $\begin{array}{l}0.0434 \\
(0.151)\end{array}$ \\
\hline Constant & $\begin{array}{c}1.455^{* * *} \\
(0.233)\end{array}$ & $\begin{array}{c}1.464 * * * \\
(0.247)\end{array}$ & $\begin{array}{c}22.19 \\
(27.17)\end{array}$ & $\begin{array}{l}71.97 * * \\
(31.25)\end{array}$ & $\begin{array}{l}72.04 * * \\
(31.28)\end{array}$ \\
\hline Database Dummies included & $\sqrt{ }$ & $\sqrt{ }$ & $\sqrt{ }$ & $\sqrt{ }$ & $\sqrt{ }$ \\
\hline Number of Primary Estimations & 238 & 238 & 238 & 238 & 238 \\
\hline Adj. $\mathrm{R}^{2}$ & 0.269 & 0.265 & 0.423 & 0.451 & 0.448 \\
\hline
\end{tabular}

Regressions of the semi-elasticity found in primary studies on respective study characteristics. All study/model characteristics are coded as dummy variables (except Average Sample Year). Thus, a base model represents the characteristics redundant to the variables explicitly included. Results are from WLS estimation. Standard errors robust to heteroskedasticity in parentheses; $* * * / * * / *$ denotes significance at the $1 \% / 5 \% / 10 \%$ level. 
Considering the previously defined benchmark study for specification (4) of Table 2, we finally get a predicted tax semi-elasticity of about 4.1. Hence, the hypothetical benchmark study would predict the profit measure of a subsidiary to increase by 4.1 percent if the tax rate incentive rises by one percentage point. Note that the benchmark specification does not display any of the study characteristics reflected by meta-variables that are statistically significant in our metaregression in Column (4). Most probably, the predicted effect is significantly overestimated due to misspecification biases. The predicted tax semi-elasticity for this hypothetical case, however, is a good starting point for a systematic discussion of the meta-regression results and potential sources of misspecification biases.

\subsection{Sources of Variation}

We focus the discussion of the meta-regression results mainly on our preferred specification (4) in Table 2. The first set of meta-variables considers the scope of profit shifting analyzed by the underlying primary studies. While most studies have estimated a tax response of subsidiary pre-tax profit, a few studies used EBIT as their dependent variable. The two dependent variables mainly differ with respect to the inclusion of interest expenses. By means of meta-regressions, we can isolate the variation in empirical results caused by the inclusion of financial policy on the left-hand side of the primary regression equations, given that all other major study characteristics are held constant. The coefficient for the after-financing dummy, which marks primary estimates of the tax-motivated shifting effect on total profit, is clearly positive in all specifications and significantly different from zero. Specification (4), for example, suggests that the tax semi-elasticity is 0.346 percentage point higher for pre-tax profit compared to the result for EBIT. We thus con-

clude that there is indeed robust evidence for a significant difference in the responsiveness of 
after-financing and before-financing profitability with respect to international profit-shifting incentives.

It is beneficial to take advantage of this empirical finding and infer some conclusions on the economic significance of the two most important profit-shifting channels, financial structures and non-financial techniques such as transfer pricing and licensing. We will return to this matter in Section 5.

A few studies also attempt to isolate the tax effect on reported profits that goes via nonfinancial techniques by holding debt levels constant on the right-hand side of their regressions. Our meta-regression results show that estimated tax response of subsidiary profit is indeed significantly smaller if a control for a subsidiary's debt share is included. The reduction in estimated tax effects is indeed very similar to the difference in tax effects on profit vs. EBIT.

Furthermore, we distinguish whether the dependent variable of primary studies considers pretax or after-tax profits. Pre-tax profit measures are not directly affected by tax payments. Only behavioral responses to taxes like cross-border shifting techniques can explain an inverse correlation between taxes and pre-tax profitability. If, however, profitability is measured after taxes, the direct effect of tax payments adds to any tax impact on reported profitability. Our metaregression results support the view that tax effects are significantly overestimated if measured after taxes. Moreover, the coefficient of about -1 is strikingly consistent with the expected difference in the tax response of profitability measured after and before taxes. Since the dependent variable of our meta-regression is the percentage change in reported profits if the tax rate varies by one percentage point, we expect a coefficient of exactly -1 . 
The third set of meta-variables considers whether the primary empirical investigation was designed to isolate pure profit-shifting effects from real activity location effects induced by international tax differences. Table 2 displays robust evidence that MNEs' efforts to shift profits towards low-tax jurisdictions are overestimated if empirical approaches do not control for the size of the local affiliate. Including a control for the size of the real activity leads to a tax semi-elasticity that is smaller by about 0.571 . Mixing investment shifting and profit-shifting effects of international tax rate differences can thus be quite misleading with regard to identified effect sizes. The robustness check in Column (5) suggests that the control for affiliate capital is most important while the control for affiliate payroll does not affect estimated tax effects on reported profitability.

In addition, we consider the influence of a refined measure for the international tax incentive including the worldwide tax rate differentials of an MNE. The results suggest that a refined tax measure leads to significantly smaller estimated semi-elasticities. In other words, focusing on host country taxes only and leaving variation in taxes at other company locations uncontrolled is indeed associated with a significant omitted variable bias in estimated tax effects. This finding highlights the importance of a thoughtful construction of the tax incentive measure to be used.

The tax incentive to shift profits might be different if some subsidiaries incur losses. Then, an additional dollar of profit shifting does not immediately avoid taxes and might only increase a loss carryforward. We therefore expect some measurement error for a tax proxy like the statutory tax rate if loss making firms are not excluded from the data sample. Our meta-regression, however, does not support the view that the exclusion of loss-making firms is associated with significantly higher tax effects. 
Regarding underlying data characteristics, studies using micro-level firm data find significantly smaller tax effects on reported profitability. The magnitude of the coefficient of about 2 is striking. We conclude that aggregated data are associated with a significant upward bias in estimated tax effects. The misleadingly high tax effect might be attributed to the problem of an ambiguous identification of pure shifting effects in aggregated data.

Moreover, regression results in Table 2 suggest that reported tax semi-elasticities seem to fall with an increasing average sample year. The response of one dollar of subsidiary's true profit slightly decreases. This effect, however, does not suggest that tax base erosion by means of profit shifting has shrunk over the last decades. Regardless, absolute profit-shifting volumes might have risen because the size of multinational businesses has extremely increased during the last decades.

Regarding the influence of the econometric specification, the inclusion of industry effects into primary regressions does significantly affect estimated tax effects. Carefully controlling for the heterogeneity in shifting opportunities, for example, due to the different share of unique and therefore incomparable transactions is associated with significantly higher estimated tax effects.

Interestingly, we find that modeling time fixed effects is not associated with a significantly higher reported tax-responsiveness of subsidiary profit. Moreover, the inclusion of firm fixed effects does not affect estimated tax semi-elasticity of reported profits.

In sum, the regression results depict significant influence of study characteristics on estimates for the tax semi-elasticity. Let us consider, for example, a study that deviates from the benchmark case with respect to all study characteristics that prove to be significant in our preferred regression (4) of Table 2. Then, the predicted tax semi-elasticity of a subsidiary's pre-tax profit is 0.82 . That means that a one percentage point smaller tax rate differential, for example, as a conse- 
quence of a one percentage point cut in host country taxes, is associated with an increase in a subsidiary's pre-tax profit by approximately 0.82 percent. This semi-elasticity can be interpreted as a consensus estimate based on the available evidence provided by 25 empirical studies and corrected for misspecification biases.

\section{Which Shifting Route is More Important?}

We finally want to discuss the quantitative implications of the meta-regression results depicted in Table 2. More specifically, we ask which profit-shifting route, financial structure or nonfinancial techniques like transfer pricing, is more important.

To answer our question, we are, first of all, interested in the shifting amount that can be exclusively attributed to non-financial shifting techniques. To this end, it is essential to know the semielasticity of pre-tax profits that would occur if no financial shifting techniques were available. Fortunately, a number of studies have estimated the semi-elasticity of a profit measure that is only responsive to non-financial shifting techniques: EBIT. By exploiting the evidence from these studies we can, based on our meta-regression results in Table 2, also predict a consensus estimate for the tax semi-elasticity of EBIT. Relative to the prediction based on regression (4) of Table 2 put forward in the previous section, we now substitute profit for EBIT as the dependent variable of the hypothetical study. All other characteristics of this hypothetical study are left unchanged. In other words, we set the dummy variable After-Financing Profitability to zero for the purpose of the new prediction but evaluate all other meta-regressors at the same values as in the previous prediction. Given the significant and positive coefficient of After-Financing Profitability, the semi-elasticity of before-financing profit, i.e. EBIT, is, all other things equal, predicted to be significantly smaller than the respective semi-elasticity of after-financing profits. For quantification, we again refer to the results of our preferred specification (4) of Table 2. Considering the 
coefficient of After-Financing Profitability which amounts to 0.346 and the predicted semielasticity of pre-tax profits of 0.82 (cf. the previous section), the predicted semi-elasticity of EBIT is $0.475(=0.821-0.346)$.

However, the two semi-elasticities of pre-tax profit (0.82) and EBIT (0.475) are not immediately comparable because they are defined with respect to different bases. The semi-elasticity of pre-tax profit, by definition, relates induced - financial and non-financial - shifting volumes to pre-tax profits. The semi-elasticity referring to EBIT instead relates the change in - exclusively non-financial - shifting volumes to EBIT. To be able to compare the two, we must relate induced non-financial shifting volumes, i.e. the induced change in EBIT, also to pre-tax profits. Equation (6) shows that this can simply be achieved by multiplying the semi-elasticity of EBIT, $\gamma_{E B I T}$, by the ratio of EBIT over pre-tax profits. Multiplying yields the semi-elasticity of pre-tax profit caused by non-financial shifting techniques, $\gamma_{N F}$.

$$
\gamma_{N F}=\gamma_{E B I T} \frac{E B I T_{i}}{P_{i}}
$$

Obviously, it is of crucial importance to find convincing and representative information on the quantitative relation between true EBIT and pre-tax profit $P$. To meet this requirement, we refer to all firms included in the S\&P 500 as our database of multinational activity. Moreover, we consider only data from consolidated financial accounts which itself cannot be affected by profit shifting. Profit-shifting activities like intra-firm debt allocation or transfer pricing are not disclosed in consolidated accounts because all intra-firm transactions cancel out. Since we are interested in measures of the profit-shifting response, it is important to use data clear of profit-shifting effects when making statements about the representative ratio of EBIT over pre-tax profit. 
The 2011 mean ratio of EBIT over pre-tax profits of all companies in the S\&P 500 is 1.25 . In other words, we find that EBIT exceeds pre-tax profits, on average, by $25 \%$. Consistently, we pre-multiply the semi-elasticity of EBIT with a factor of 1.25 to align its basis to the semielasticity of pre-tax profits - and to make it, thus, comparable. The resulting semi-elasticity of $0.594(=0.475 * 1.25)$ approximates the percentage change in pre-tax profits in response to a 1 percentage point change in the tax incentive to shift profits abroad. Since it is still driven by the response in EBIT, it exclusively reflects shifting volumes going through non-financial routes.

Table 3: Predicted Semi-Elasticities

\begin{tabular}{lccc}
\hline \hline \multirow{2}{*}{ Shifting Techniques } & \multicolumn{2}{c}{ Semi-elasticity of } & $\begin{array}{c}\text { Share of underly- } \\
\text { ing technique in } \\
\text { total response }\end{array}$ \\
\cline { 2 - 4 } & EBIT & $\begin{array}{c}\text { Pre-Tax } \\
\text { Profit }\end{array}$ & $100 \%$ \\
All & - & 0.821 & $72 \%$ \\
Financial & 0.475 & 0.594 & $28 \%$ \\
\hline \hline
\end{tabular}

Predicted semi-elasticities of profit measures considering the meta-regression results from specification (4) in Table 4 and information on the typical ratio between pre-tax profit and EBIT from the 2011 financial accounts of the S\&P 500 firms.

Table 3 summarizes the semi-elasticities derived above and also indicates the shifting techniques they reflect. Based on regression (4) of Table 2, we predict a typical semi-elasticity of pretax profit to be about 0.821 . Furthermore, the semi-elasticity of pre-tax profit attributable only to non-financial shifting techniques was calculated to approximate a value of 0.594 . With the overall semi-elasticity of pre-tax profits predicted to be 0.821 and the non-financial part of the response accounting for 0.594 , the response from purely financial adjustments is just the residual of $0.227(=0.821-0.594)$.

In brief, referring to the ratio of EBIT to pre-tax profits identified as representative for the S\&P 500 we can plausibly approximate the non-financial and the financial part of the pre-tax 
profit response to the international shifting incentive. Their respective share in the overall response gives an insight into the relative importance of financial vs. non-financial profit-shifting mechanisms. Looking at the numbers in Table 3, the ratio of the non-financial response to the total response is $0.72(=0.594 / 0.821)$. Thus, according to our approximate calculations, nonfinancial shifting mechanisms account for $72 \%$ of the overall pre-tax profits response to a change in the tax incentive to shift profits abroad. The residual share of $28 \%$ can be attributed to financial shifting channels.

\section{Conclusion}

In this study, we present a meta-analysis covering 25 studies on corporate profit-shifting behavior. We first transform the reported empirical results into a uniformly defined semi-elasticity for the tax effect on the analyzed profit-shifting indicator. We regress the assembled semielasticities on different sets of mostly dummy variables which mark, inter alia, the employed dependent variables serving as proxies for profit-shifting activity, the control for the size of affiliates' real economic activity, underlying data characteristics and the different econometric approaches. Accounting for all potential misspecification biases, we predict a tax-semi elasticity of pre-tax profit of about 0.8 . That means a one percentage point smaller tax rate differential exploitable for tax arbitrage, for example, as a consequence of a one percentage point cut in host country taxes, is associated with an increase in a subsidiary's pre-tax profit by approximately 0.8 percent. This semi-elasticity can be interpreted as a consensus estimate based on all available evidence and corrected for all misspecification biases.

The meta-regression analysis suggests that leaving tax-induced real economic location effects unmodeled significantly overestimate the tax-responsiveness of pure paper profit shifting. This is 
also true if aggregated data are used or profitability is measured after taxes or if the international tax incentive within MNEs is not carefully modeled. Moreover, we find that a control for unobserved heterogeneity in shifting opportunities across industries is associated with significantly higher tax effects on reported profit.

Most important, we find a significantly higher tax semi-elasticity of subsidiary profit compared to EBIT. This seems like a promising approach to infer some insights on the relative economic importance of the distinct profit-shifting channels which are either based on transfer pricing strategies or onthe financial policy of firms.

Our results indeed provide evidence that the two profit-shifting channels, corporate financial policy and tax-motivated adjustments of related-party transactions, are not equally important. In particular, we find some tentative evidence that the volumes of shifted tax bases are to a large extent, i.e. two-thirds, driven by firms' non-financial inter-company transactions. From the point of view of national governments and tax administrations, this finding can have important implications. The extent of tax base erosion is not determined by the mere responsiveness of the shifting strategies, but also by the tax base volume effectively shifted via the respective channels.

Regardless of whether anti-avoidance measures are at all desirable, the discussion on multinational profit-shifting and anti-avoidance legislation is very much centered on the financial strategies of firms. Given our findings, doubts remain as to whether this policy matches the true proportion, in terms of the lost taxable bases, of the two shifting channels. If policy makers want to effectively restrict profit-shifting opportunities of MNEs, restricting transfer pricing and royalties remains a challenging task in anti-tax-avoidance legislation as well. 
Finally, the results of our meta-analysis can guide further empirical research. Future research can benefit from the insights on how various study characteristics quantitatively affect estimated tax effects. Moreover, it might be an interesting challenge to consider the scope of profit shifting more carefully. In particular, estimates of the pure tax response of reported profits to royalty payments are generally lacking. 


\section{Appendix}

Table 4: Studies on Profit Shifting Behavior Included in the Meta-Analysis

\begin{tabular}{|c|c|c|c|c|c|c|c|}
\hline \multirow{2}{*}{ Study } & \multirow{2}{*}{$\begin{array}{l}\text { Dep. } \\
\text { Variable }\end{array}$} & \multirow{2}{*}{$\begin{array}{l}\text { No. of } \\
\text { effects }\end{array}$} & \multicolumn{5}{|c|}{ Semi-Elasticities } \\
\hline & & & Mean & Median & Min & Max & Std. \\
\hline Azemar, 2010 & Profit & 3 & 2.75 & 1.60 & 1.02 & 5.62 & 2.51 \\
\hline Becker and Riedel, 2012 & Profit & 3 & 0.78 & 0.75 & 0.73 & 0.84 & 0.06 \\
\hline Blouin et al., 2012 & Profit & 11 & 0.31 & 0.24 & 0.15 & 0.89 & 0.22 \\
\hline Clausing, 2009 & Profit & 4 & 3.39 & 3.50 & 1.05 & 5.52 & 1.83 \\
\hline Collins et al., 1998 & Profit & 2 & 0.32 & 0.32 & -0.32 & 0.96 & 0.90 \\
\hline De Simone, 2012 & Profit & 3 & 0.74 & 0.75 & 0.71 & 0.76 & 0.03 \\
\hline Dharmapala and Riedel, 2012 & Profit & 1 & 1.13 & 1.13 & 1.13 & 1.13 & - \\
\hline Dischinger, 2010 & Profit & 16 & 1.60 & 1.54 & 0.72 & 3.32 & 0.75 \\
\hline Dischinger and Riedel, 2011 & Profit & 4 & 3.20 & 3.18 & 2.14 & 4.29 & 1.11 \\
\hline Dischinger and Riedel, 2013 & Profit & 12 & 0.72 & 0.67 & -0.02 & 1.70 & 0.53 \\
\hline Grubert, 2003 & Profit & 5 & 0.80 & 0.77 & 0.48 & 1.05 & 0.22 \\
\hline Grubert, 2012 & Profit & 14 & 1.29 & 1.29 & 0.63 & 2.31 & 0.46 \\
\hline Hines and Rice, 1994 & Profit & 4 & 12.29 & 9.64 & 5.59 & 24.30 & 8.67 \\
\hline Huizinga and Laeven, 2008 & Profit & 3 & 1.21 & 0.90 & 0.73 & 2.00 & 0.69 \\
\hline Klassen und Laplante, 2012a & Profit & 8 & 1.12 & 1.01 & 0.88 & 2.02 & 0.38 \\
\hline Klassen und Laplante, 2012b & Profit & 6 & 0.85 & 0.84 & 0.19 & 1.47 & 0.41 \\
\hline Loretz and Mokkas, 2011 & Profit & 12 & 1.01 & 0.85 & -0.30 & 3.42 & 1.10 \\
\hline Markle, 2012 & Profit & 15 & 0.98 & 0.94 & -0.41 & 2.04 & 0.67 \\
\hline Mills and Newberry, 2004 & Profit & 4 & 1.94 & 1.03 & -1.16 & 6.86 & 3.79 \\
\hline Rousslang, 1997 & Profit & 12 & 4.74 & 5.00 & 3.63 & 5.63 & 0.64 \\
\hline Schwarz, 2009 & Profit & 9 & 2.27 & 2.16 & -1.33 & 4.81 & 2.01 \\
\hline Weichenrieder, 2009 & Profit & 10 & 0.80 & 0.81 & 0.44 & 1.16 & 0.24 \\
\hline Beuselinck et al., 2009 & EBIT & 4 & 0.58 & 0.61 & 0.21 & 0.87 & 0.27 \\
\hline Hines and Rice, 1994 & EBIT & 6 & 1.34 & 2.54 & -5.91 & 3.65 & 3.59 \\
\hline Huizinga and Laeven, 2008 & EBIT & 24 & 1.25 & 0.92 & 0.49 & 3.71 & 0.70 \\
\hline Loretz and Mokkas, 2011 & EBIT & 12 & 0.38 & 0.13 & -0.79 & 1.81 & 0.85 \\
\hline Maffini and Mokkas, 2011 & EBIT & 22 & 1.21 & 1.03 & 0.23 & 4.87 & 0.96 \\
\hline McDonald, 2008 & EBIT & 9 & 1.23 & 1.03 & 0.60 & 2.14 & 0.52 \\
\hline Profit & & 161 & 1.78 & 0.97 & -1.33 & 24.30 & 2.54 \\
\hline EBIT & & 77 & 1.07 & 1.01 & -5.91 & 4.87 & 1.22 \\
\hline Full Sample & & 238 & 1.55 & 0.99 & -5.91 & 24.30 & 2.23 \\
\hline
\end{tabular}




\section{References}

Adam, A., P. Kammas and A. Lagou (2013), The Effect of Globalization on Capital Taxation: What have we Learned after 20 Years of Empirical Studies?, Journal of Macroeconomics 35, $199-209$.

Altshuler, R. and H. Grubert. (2006). Governments and Multinational Corporations in the Race to the Bottom. Tax Notes International 41:459-74.

Azemar, C. International Corporate Taxation and U.S. Multinationals' Behavior, Canadian Journal of Economics 43, 232-253.

Bartelsman, E. J. and R. M. W. J. Beetsma. (2003). Why Pay More? Corporate Tax Avoidance through Transfer Pricing in OECD Countries. Journal of Public Economics 87: 2225-2252.

Becker, J. and N. Riedel (2012), Cross-Border Tax Effects on Affiliate Investment - Evidence from European Multinationals, European Economic Review 56, 436-450.

Beuselinck, C., M. Deloof and A. Vanstraelen. (2009). Multinational Income Shifting, Tax Enforcement and Firm Value. Working Paper, University of Tilburg.

Blouin, J., L. Robinson and J. Seidman. (2012). Coordination of Transfer Prices on Intra-Firm Trade. Tuck School of Business Working Paper No. 2010-74, Dartmouth.

Buettner, T., M. Overesch, U. Schreiber and G. Wamser. (2012). The Impact of ThinCapitalization Rules on the Capital Structure of Multinational Firms, Journal of Public Economics 96, 930-938.

Card, D. and A.B. Krueger, 1995. Time-Series Minimum-Wage Studies: A Meta-Analysis, American Economic Review (Papers and Proceedings) 85, 238-43.

Card, D., Kluve, J., Weber, A., 2010. Active Labor Market Policy Evaluations: A Meta-analysis. Economic Journal 120, F452-F477.

Clausing, K. A. (2003). Tax-Motivated Transfer Pricing and US Intrafirm Trade Prices. Journal of Public Economics 87: 2207-2223.

Clausing, K. A. (2006). International Tax Avoidance and US International Trade. National Tax Journal 59: 269-287.

Clausing, K. A. (2009). Multinational Firm Tax Avoidance and Tax Policy. National Tax Journal 62: 703-725.

Collins, J., D. Kemsley and M. Lang. (1998). Cross-Jurisdictional Income Shifting and Earnings Valuation. Journal of Accounting Research 36: 209-229.

De Long, J. B. and K. Lang. (1992). Are All Economic Hypotheses False?. Journal of Political Economy 100: 1257-72.

De Mooij, R. A. and S. Ederveen. (2003). Taxation and Foreign Direct Investment: A Synthesis of Empirical Research. International Tax and Public Finance 10: 673-693.

De Simone, L. 2012. Does a Common Set of Accounting Standards Affect Tax-Motivated Income Shifting for Multinational Firms? Working Paper, University of Texas at Austin.

Desai, M. A., C. F. Foley and J. R. Hines. (2004). A Multinational Perspective on Capital Structure Choice and Internal Capital Markets. Journal of Finance 59: 2451-2487. 
Devereux, M. P., C. Elschner, D. Endres and C. Spengel. (2009). Effective Levels of Company Taxation within an Enlarged EU. Study prepared for the European Commission, Update 2009, Mannheim and Oxford.

Dharmapala, D. and N. Riedel. (2012). Earnings Shocks and Tax-Motivated Income-Shifting: Evidence from European Multinationals, Journal of Public Economics 97, 95-107.

Dischinger, M. (2010). Profit Shifting by Multinationals: Indirect Evidence from European Micro Data. Discussion Paper, Ludwig-Maximilians-University Munich.

Dischinger, M. and N. Riedel. (2013), The Role of Headquarters in Multinational Profit Shifting Strategies, International Tax and Public Finance, forthcoming.

Dischinger, M. and N. Riedel. (2011). Corporate Taxes and the Location of Intangible Assets within Multinational Firms. Journal of Public Economics 95: 691-707.

Disdier, A. C., and K. Head, 2008. The Puzzling Persistence of the Distance Effect on Bilateral Trade. Review of Economics and Statistics 90, 37-48.

Doucouliagos, H., Stanley, T.D., Giles, M., 2012. Are Estimates of the Value of a Statistical Life Exaggerated? Journal of Health Economics, forthcoming.

Dyreng, S. D., M. Hanlon and E. L. Maydew. (2008). Long Run Corporate Tax Avoidance.

Dyreng, S. D., M. Hanlon and E. L. Maydew. (2010). The Effects of Executives on Corporate Tax Avoidance, Accounting Review, 85(4): 1163-1189.

Égert, B., Halpern, L., 2006. Equilibrium exchange rates in Central and Eastern Europe: A metaregression analysis. Journal of Banking and Finance 30, 1359-1374.

Feld, L. P. and J. H. Heckemeyer. (2011). FDI and Taxation: A Meta-Study. Journal of Economic Surveys 25: 233-272.

Feld, L. P., J. H. Heckemeyer and M. Overesch. (2013). Capital Structure Choice and Company Taxation: A Meta-Study. Journal of Banking and Finance, forthcoming.

Florax, R., H. de Groot and R. de Mooij. (2002). Meta-Analysis in Policy-Oriented Research. CPB Report 2002/1: 21-25.

Greene, W.H., 2003. Econometric Analysis. Prentice Hall, Upper Saddle River, NJ.

Grubert, H. (1998). Taxes and the Division of Foreign Operating Income Among Royalties, Interest, Dividends and Retained Earnings. Journal of Public Economics 68: 269-290.

Grubert, H. (2003). Intangible Income, Intercompany Transactions, Income Shifting, and the Choice of Location. National Tax Journal 56: 221-242.

Grubert, H. (2013). Foreign Taxes and the Growing Share of U.S. Multinational Company Income Abroad: Profits, Not Sales, Are Being Globalized, National Tax Journal 65, 247-81.

Grubert, H. and J. Mutti. (1991). Taxes, Tariffs and Transfer Pricing in Multinational Corporate Decision Making. Review of Economics and Statistics 73: $285-293$.

Havranek, T., Irsova, Z., (2011), Estimating Vertical Spillovers from FDI: Why Result Vary and What the True Effect Is. Journal of International Economics 85, 234-244.

Hines, J.R. and E.M. Rice. (1994). Fiscal Paradise: Foreign Tax Havens and American Business. Quarterly Journal of Economics 109: 149-182. 
Huizinga, H. and L. Laeven. (2008). International Profit Shifting within Multinationals: A MultiCountry Perspective. Journal of Public Economics 92: 1164-1182.

Huizinga, H., L. Laeven and G. Nicodème. (2008). Capital Structure and International Debt Shifting in Europe. Journal of Financial Economics 88: 80-118.

Jacob, J. (1996). Taxes and Transfer Pricing: Income Shifting and the Volume of Intra-Firm Transfer. Journal of Accounting Research 34: 301-312.

Klassen, K.J. and S.K. LaPlante. (2012a), Are U.S. Multinational Corporations Becoming More Aggressive Income Shifters? Journal of Accounting Research 50, 1245-1285.

Klassen, K.J. and S.K. LaPlante. (2012b), The Effect of Foreign Reinvestment and Financial Reporting Incentives on Cross-Jurisdictional Income Shifting, Contemporary Accounting Research 29, 928-955.

Loretz, S. and S. Mokkas (2011). Evidence for Profit Shifting with Tax Sensitive Capital Stocks OUCBT Working Paper 11/16, Oxford.

Maffini, G. and S. Mokkas. (2011). Profit Shifting and Measured Productivity of Multinational Firms. Oxford Bulletin of Economics and Statistics 73: 1-20.

Markle, K. S. (2012). A Comparison of the Tax-Motivated Income Shifting of Multinationals in Territorial and Worldwide Countries. OUCBT Working Paper 12/06, Oxford.

McDonald, M. (2008). Income Shifting from Transfer Pricing: Further Evidence from Tax Return Data. OTA Technical Working Paper 2, Department of the Treasury, Washington D.C.

Mills, L. F. and K. J. Newberry. (2004). Do Foreign Multinational's Tax Incentives Influence their U.S Income Reporting and Debt Policy?. National Tax Journal 57: 89-107.

OECD (2013), Addressing Base Erosion and Profit Shifting, Paris.

Rousslang, D. J. (1997). International Income Shifting by US Multinational Corporations. Applied Economics 29: 925-934.

Schwarz, P. (2009). Tax-Avoidance Strategies of American Multinationals: An Empirical Analysis. Managerial and Decision Economics 30: 539-549.

Stanley, T. D. (2001). Wheat from Chaff: Meta-Analysis as Quantitative Literature Review. Journal of Economic Perspectives 15: 131-150.

Stanley, T. D. (2005). Beyond Publication Bias. Journal of Economic Surveys 19: 309-345.

Stanley, T. D. (2008). Meta-Regression Methods for Detecting and Estimating Empirical Effects in the Presence of Publication Selection. Oxford Bulletin of Economics and Statistics 70: 103-127.

Steiner, V. (2008). Review of Fundamental Capital Income Tax Reforms - Discussion and Simulation Using IFOmod, by M. Stimmelmayr. Journal of Economics 94: 279-282.

Sullivan, Martin A. (2012). Apple Reports High Rate but Saves Billions on Taxes, Tax Notes 134: $777-778$.

Weichenrieder, A. (2009). Profit Shifting in the EU: Evidence from Germany. International Tax and Public Finance 16: 281-297.

Wooldridge, J.M. (2002). Econometric Analysis of Cross-Section and Panel Data, Cambridge. 